\title{
Digital storytelling of English advertisement in ESP teaching in Indonesia
}

\author{
${ }^{1}$ Rizki Puji Lestari, ${ }^{1 D e l i ~ N i r m a l a * ~}$ \\ ${ }^{1}$ Applied Linguistics Program, Faculty of Humanities, Universitas Diponegoro, \\ Indonesia \\ *Corresponding Author \\ Email: delinirmala@live.undip.ac.id
}

\begin{abstract}
This paper discusses the benefits of by using digital storytelling in order to improve the polytechnic learners in learning activity of English for Specific Purposes. In this case, digital storytelling is used as advertising media for promoting agricultural products in English registered in Technology of Agricultural Product study program at PDD UNS, Indonesia. The subjects of this research were fourth semester learners of Technology of Agricultural Product in PDD UNS who followed English 2 class. The data were collected from the learners' surveys and the video projects. The method of this research was descriptive qualitative research to evaluate the learners English public speaking in product advertisement by using digital storytelling. The result shows that digital storytelling is a useful learning approach to improve both non-linguistic skills and productive linguistic skills in English advertisement. There were some weaknesses of by using digital storytelling in English learning. The learners would have some difficulties if there was no internet access. Besides, electronic tools such as handycam or camera recorder is needed to record the video. Then, a video-editing skill also can be determining whether the video plot is good or not. According to the result which has shown above, it can be stated that the activeness of the learners depend on how the lecturer bring the material during teaching learning process. Through the attractive teaching method or technique, it can help the learners to build their self-confidence.
\end{abstract}

Keywords: digital storytelling; English for Specific Purposes; polytechnic education; advertisement; technology

Received:

31 May 2019
Revised:

26 January 2019
Accepted:

6 February 2020
Published:

29 February 2020

\section{INTRODUCTION}

The fourth industrial revolution (Industry 4.0) refers to the process of automation and data exchange that have prospects for a greater use in the manufacturing technologies in Indonesia. There are many countries which have developed strategies to capitalize on this technology. Therefore, Indonesia's government has started to launch Making Indonesia 4.0 in 2018. This roadmap focuses on the five areas namely food and beverages, textiles, automotive, electronics, and chemicals. According to the data as reported by 
Lestari, R.P., \& Nirmala, D.(2020). Digital storytelling of English advertisement in ESP teaching in Indonesia. EduLite: Journal of English Education, Literature, and Culture, 5 (1), 66-77. DOI: http://dx.doi.org/10.30659/e.5.1.66-77

the McKinsey which is stated in online sites news on theinsiderstories.com, Indonesia has a big opportunity in the Industry 4.0 by speeding up the digital economy. Indonesia can earn up to US\$150 billion in annual economic impact by 2025 .

One of the challenges to bring Indonesia in Industry 4.0 is the readiness of human resources. Indonesia has the fourth largest workface in the world but lack in talent. It was proved by the data of Manpower Ministry, stated that Indonesia is dominated by the unskilled labour with a percentage of 60.24 percent of total 125.44 million labours. The skilled labour with the bachelor degree certificate is only 11.65 million labours. According to the research published by McKinsey Global Institute (MGI) towards the data information above, the Indonesia's opportunity to become the seventh biggest economy in 2030 seems very low, so it needs 113 million of skilled labours. Besides that, the low rate of skilled labours in line with the tiny government budget on education is only US\$114 per capita. In addition, Indonesian government only has a tight budget for the research and development around $0.1 \%$ to $0.3 \%$ of GDP (Gross Domestic Product). It can be stated that Indonesian government plans the research and development budget to rise at least $2 \%$ to enter the real Industry 4.0.

Nasir (2019) states that fourth industrial revolution needs learners who are able to adapt the possibility of total machination in industrial activities. Therefore, the polytechnic learners specifically could learn from sources outside their classes to improve their creativity. He also emphasized that there are various kinds of literacies learners must be possessed in the 4.0 industrial revolution era such as data literacy, technology literacy, language literacy and human literacy. In addition, the polytechnic lecturers are asked to teach the literacies above to the learners through assisting the learners in getting working experience while studying as well as teaching them to become innovative. It can be stated the development of 4.0 industrial revolution era can be implemented through teaching learning process to the polytechnic learners to prepare them as skilled labours in the real workfield.

According to the explanation above, the primary objective of engineering study program of polytechnic level in PDD UNS is to produce the best technicians by comparing the growing needs of the industries with the academic input. The participation of English language teaching in PDD UNS is to develop the communication skills and soft skills at the undergraduate level. Through English teaching program, it will prepare the polytechnic learners as skilled-technicians in the future that can develop their network up to the foreign level. The English materials are taught differently in each different faculty in PDD UNS. It depends on its concentration of study program. In this study, the researcher took the learners of Technology of Agricultural Product study program as the subject of the research. This study program learns English related on food's nutrient standard, processing, and marketing of the agricultural product. The learners have developed agricultural products especially in Madiun's traditional products, such as Kare Coffee, Kare Chocolates, cassava chips, Puli chips, Banana Ledre, Brem, and so on. They also have collaborated with the traditional farmers to process its products. Even though the learners could process it expertly, they still confuse to market the products up to the foreign industry. In addition, the learners and the 
farmers only market the products in Madiun area as traditional food souvenirs. Only local tourists who do traveling to Madiun as the buyers of the traditional food souvenirs.

Digital storytelling is one of interactive communication methods in the system of entertainment and information by using digital media. Digital storytelling may affect many other fields such as politics, education, consumption, and so on. The storytellers can convey their messages to look more personal and being closer to the listeners. It can be as an appropriate way to promote products in advertising sector, because the sellers can inform the advertising message to their customers directly. The researcher asked the polytechnic learners of Technology of Agricultural Product study program in PDD UNS to use digital storytelling to promote their products in English by using digital media because very little research has been undertaken to investigate potential benefits of digital storytelling in English advertisement.

The researcher as the English lecturer of Technology of Agricultural Product study program in PDD UNS initiates to develop a strategy of how to market the agricultural product in PDD UNS. The researcher tried to combine the learners' agricultural knowledge and English material especially in advertisement through digital storytelling. The learners were developed themselves as skilled-marketers besides as skilled-technicians in the agricultural industry. The researcher hopes that the learners can develop their potential products up to export level. Automatically, the learners should learn how to communicate the products to their customers clearly. If the learners expert to promote the products to the customers interactively, it will open their opportunity to develop their marketplace up to export level.

Robin (2008) states the first application of multimedia technology in the classroom for educational purposes is introduced by Lambert and Atchley who helped the advent of digital storytelling movement in the late 1980s as cofounders of Center for Digital Storytelling (CDS) in Berkeley, California. Robin (2008) also compares the result of his studies about the improvement of the learners who were asked to create their own digital stories in the classroom, either as independently or part of a small group. Alexander (2011, 27), a lecturer in California State University, has formed a comprehensive five part definitions of digital stories as follow.

1. Include a compelling narration of a story;

2. Provide a meaningful context for understanding the story which is being told;

3. Use images to capture the emotions which is found in the narrative;

4. Employ music and other sound effects to reinforce the ideas;

5. Invite thoughtful reflection from the audiences.

Rance and Roney $(2008,30)$ state that digital storytelling can assist learning process effectively in EFL classrooms, because it can develop multimodal communicative competence by promoting a learner-centred environment to the EFL learners. In addition, the learners can narrate the scripts of their stories and record themselves through digital storytelling. Besides that, it will be mixed with different types of multimedia, such as computer based graphics, computer-generated text, images, video clips and music, so that it can be played on a computer. On the other hands, Kajder 
Lestari, R.P., \& Nirmala, D.(2020). Digital storytelling of English advertisement in ESP teaching in Indonesia. EduLite: Journal of English Education, Literature, and Culture, 5 (1), 66-77. DOI: http://dx.doi.org/10.30659/e.5.1.66-77

(2006) states the learners will become a "storytellers" who present the stories of various texts they have created to the audiences.

From a social constructivist perspective, Vygotsky (1978), he states that Technology Enhanced Language Learning (TELL) allows both teachers and learners to construct, share, and build the language knowledge and content knowledge together. In contrary, Lee (2011) argues that TELL can be a catalyst for the learners because they are involved in decision making and problem solving within a virtual language learning community. In addition, Lee (2014) states the emergence of Web 2.0 technology, for instance, has revolutionized the ways of both language learners and language practitioners to explore functional use of a target language (TL) and use the language within the classrooms and beyond. However, digital storytelling is one form of TELL that can minimize the learners' anxious feeling while they express themselves to their classmates than with face-to-face interaction directly. It is more effective to minimize face threatening among them, particularly in speaking foreign language by EFL learners. Lee $(2014,339)$ adds that the learners will engage in the story making and sharing process when they are working on digital storytelling. This social engagement creates a supportive learner centred of learning environment.

Burnett (2010) states that digital storytelling is a multidimensional skill which requires the learners to be literate in technology, interact with a variety of texts, and to make meaning digitally. Besides that, he proved that the learners can build and enhance critical thinking (collecting, evaluating, and synthesizing information), collaborative creativity (the blend of audio, video, and animation), problem solving (identifying and solving problems), and multiliteracies (technology literacy, genre literacy, and information literacy). In the creation of digital stories, Vinogradova, Linville, and Bickel (2011) states that the learners have the opportunity to use multiple skills, such as searching (navigating and viewing) and organizing information (knowledge building); writing a script (text construction); weaving together of the voice, images, and music; and publishing a finished online version.

Through the explanation above, it can be seen that digital storytelling is an appropriate way to prepare the polytechnic learners as skilled-labours in facing the industrial revolution 4.0 in the real workfield. One of the industrial revolution 4.0's roadmaps in Indonesia is food and beverages. Through digital storytelling, it can help the Technology of Agricultural Product's learners as business doers of food in connecting with the customers globally. Jimenez, et al. (2014) state that main goal of storytelling in marketing sector is seeking closeness, empathy, and connection with the customers who are not willing to continue consuming products as before or seeking a new way of communication to the new customers. The form of digital system to share the advertisement to the customers is social networks. It is the right place to tell the stories of the product through digital storytelling in order to promote it. Some social networks which can be used as storytelling media, such as website, youtube, instagram, facebook, and so on. Some application to edit the video of storytelling, such as Kine Master, Viva Video, Windows Movie Maker, Camtasia, and so on. On the other hands, Bourdaa (2012) stated that digital story for marketing (advertising storytelling) has three fundamental components as follow. 
1. Hypertext: nonlinear reading of speech;

2. Multimedia: use different media such as animations, audio, video, and so on;

3. Interaction: the user can choose and execute the system of its own action.

There are many researchers have conducted the research of digital storytelling in various ways. Campbell (2012) conducted the research of digital storytelling in a junior elementary school classroom. The result proved that the junior elementary learners enhance the engagement in writing as well as the motivation and ability to create higher quality writing. They are excited to adopt their everyday classroom literacy activities through technology, especially in reading and writing. On the other hands, Razmi, et al (2014) took a research of the use of digital storytelling in an Iranian undergraduate EFL classroom to see whether by using computer-based tools affect theimprovement of learners' narrative skills or not. Participants were divided into two groups. One group created their digital stories of the given stories selected from Perrine's literature course book to be presented in the classroom while other group was asked to read the given stories and then present them. Both groups were tested for their oral production and competence. The result showed that the learners develop better of oral skills and digital storytelling can be considered as an essential tool in foreign language learning and teaching. Then, Widodo (2016) conducted the research to engage the EFL young learners in a genre-based digital storytelling project. The learners told their holiday through digital storytelling as recount text. They used Microsoft Photo Story 3 as media of digital storytelling. He stated that even though doing a digital storytelling with young learners is a complex and staged process, but this process engages the learners in collecting, creating, analyzing, and combining visual artefact with written text. They would be familiar with computer, particularly in image capture devices. According to the results of three previous researchers above, it can be seen that digital storytelling is effective to develop English skills especially on writing, reading, and speaking towards EFL young learners. Hausknecht, et al (2018) gave a novelty of the use of digital storytelling. They took older adult as participants who attended one of thirteen courses to investigate the experiences and perceivedbenefits of the older adults who created digital stories. After that, they should explore the reactions of story viewers of their digital stories creation during a special sharing event at that moment. The result proved that digital storytelling helps the digital storytellers to increase connectedness to others and to themselves.

Although digital storytelling has been used to investigate EFL learners who took general English in classroom, it has not been so widely studied by polytechnic learners who took English for Specific Purposes (ESP). Gimeno and Sanz (2015) proved that digital storytelling was successfully implemented to the aerospace engineering learners who took ESP class in Spain. They can develop both of non-linguistic skills as well as language acquisition. They used reading and writing of engineering materials during the research. Even though digital storytelling has been studied by polytechnic learners, but they only focused on the theoretical assessment. Moreover, the researcher in this study tried to develop the novelty of the use of digital storytelling to the polytechnic learners as practically. The researcher would combine both technology of 
Lestari, R.P., \& Nirmala, D.(2020). Digital storytelling of English advertisement in ESP teaching in Indonesia. EduLite: Journal of English Education, Literature, and Culture, 5 (1), 66-77. DOI: http://dx.doi.org/10.30659/e.5.1.66-77

agricultural product skill and English skill simultaneously in this study. Through this interactive way, the researcher asked the polytechnic learners of Technology of Agricultural Product to use digital storytelling to promote their products in English by using digital media.

\section{METHOD}

The subjects of this research were fourth semester learners of Technology of Agricultural Product in PDD UNS who followed English 2 class. There were 23 learners who comprised of 19 females and 4 males. Most of them were nineteen years old. The method of this research was descriptive qualitative research to evaluate the learners English public speaking in product advertisement by using digital storytelling. In this study, the learners have to promote their products in part of small group by using digital storytelling in English. The products that they promote are some traditional food and beverages in Madiun, such as Kare Coffee, Kare Chocolates, Choco ginger drinks, cassava chips, banana ledre and soya milk. They have learnt how to process and pack the products as the materials of agricultural class in the previous semesters.

There are some implementation of creating the advertisement by using digital storytelling which have done by the learners. At the first time, the learners completed pre survey by using 5 points of Likert Scale questionnaire which are shared by the lecturer before the treatment. It aims to gain further information of their knowledge about digital storytelling. After that, the learners learnt about digital storytelling by listening the English lecturer's explanation. Then, the learners divided themselves into five groups. Each group consists of four to five learners. They created their digital stories, such as topic, setting, software, and media. Before the learners created the videos in group, the lecturer have corrected their advertising script on the paper. Besides that, the learners edited their video to synchronize voice, music, and visuals. Not only making and editing the video, but they also shared their digital stories on the social media, such as instagram, youtube, and facebook.

Therefore, the learners had to fill in the peer assessment forms for the digital stories after they watched their classmates' digital stories. The learners also replied the comments of the other peers. After that, the learners wrote their self assessment comments about their own digital advertising video. After the learners had presented the "making of" in front of their classmates and had filled in the peer assessment forms for their "making of" presentations, they completed the final survey by using 5 points of Likert Scale questionnaire.

The researcher used pre survey, self assessment, peer assessment and post survey in order to know the learners' perception. The researcher conducts pre and post surveys in order to gather as much information as possible on how the learners quantify the improvements in language performance of digital storytelling in this study. Besides that, the assessment of digital storytelling's projects have been done by themselves and their classmates simultaneously. Pre survey was conducted to the learners before the treatment in order to gain the information on how far the learners know digital storytelling is. Besides conducting pre survey before the treatment, the activity also was completed by 
final survey by using 5 points of Likert Scale questionnaire after the treatment.

\section{RESULTS AND DISCUSSION}

According to the result of pre survey, the researcher found the facts about the learners' perception towards English course. There were many learners of Technology of Agricultural Product in PDD UNS felt bored with their English lecturer's explanation before the treatment. Most of them stated that their lecturer only explained the materials and made notes on the presentation layout. The learners only listening the explanation, taking notes and asking some questions related on the explanation. It happened all the time until mid term test and final test come. The learners and the English lecturer only have one hundred minutes to study English.

In addition, the teaching and learning process have been done in the classroom without any treatment on the field directly. The learners just focused on doing apprenticeship (kerja praktek) appropriate with their concentration of study program. Meanwhile, it happened on the third semester around three months. On the other hands, the learners have lack opportunity to show up their English skill. It can be stated that the learners felt difficult to speak English fluently because they just expressed their English skill on the writing notes about grammatical structures and analyzing the text. This situation can make the learners felt hard how to expose their English speaking skill actively. They have less English speaking skill in the real activity, such as practising the product advertisement to the public media.

Because of their limitation of that chances, they felt ashamed to start speaking English. They also felt confused how to choose the appropriate English vocabulary in product advertisement. This condition certainly effected on the audiences response. The learners will fail as a skilled marketer if the audiences response are bad or there is a few audiences who give positive feedbacks. It can be stated that the learners will be being prepared as a skilled marketer in the foreign level industry without any real practice of English speaking as well as on their agricultural skill.

Another findings also found on the pre survey. Most of the learners like to use technology and social network. They usually use social media to express their feelings in daily activity. In contrary, they never tried to use it as a marketing media, especially on how to market agricultural product in English. They felt less confident to upload their creation in English advertisement. They felt afraid to choose inappropriate vocabulary, bad grammatical structures and wrong pronunciation. They only use their social media to have communication to their friends in daily conversation.

According to the result of the observation, most of the learners actually have known yet what about digital storytelling was. The learners felt interactive when the lecturer explained all about digital storytelling. They asked the lecturer to implement it into English public speaking activity than explaining the material through presentation in the classroom.

Therefore, the lecturer asked the learners to made advertisement video in English. The lecturer also were being a guidance to correct the learners' grammatical structures before making a video. The learners felt free to express their concepts in group discussion. They started to discuss about the 
Lestari, R.P., \& Nirmala, D.(2020). Digital storytelling of English advertisement in ESP teaching in Indonesia. EduLite: Journal of English Education, Literature, and Culture, 5 (1), 66-77.

DOI: http://dx.doi.org/10.30659/e.5.1.66-77

advertisement plot and content. In this case, they discussed about the setting of the video, the manuscripts of their dialogues during the video-taking and the product that they will take in. They felt free to determine one brand of Madiun traditional food. They are very enthusiastic to give their best idea to each others. The learners were active in discussion session. The discussion session was held in the classroom. Then, the video shot was held in the outdoor. The learners felt attractive and interactive on advertisement videotaking. Most of them were very happy to speak English actively. They felt very confident in promoting the product. They were not afraid in English speaking anymore. They were laughing together during video-taking. Balancing learning activity in indoor have avoided them in boring situation.
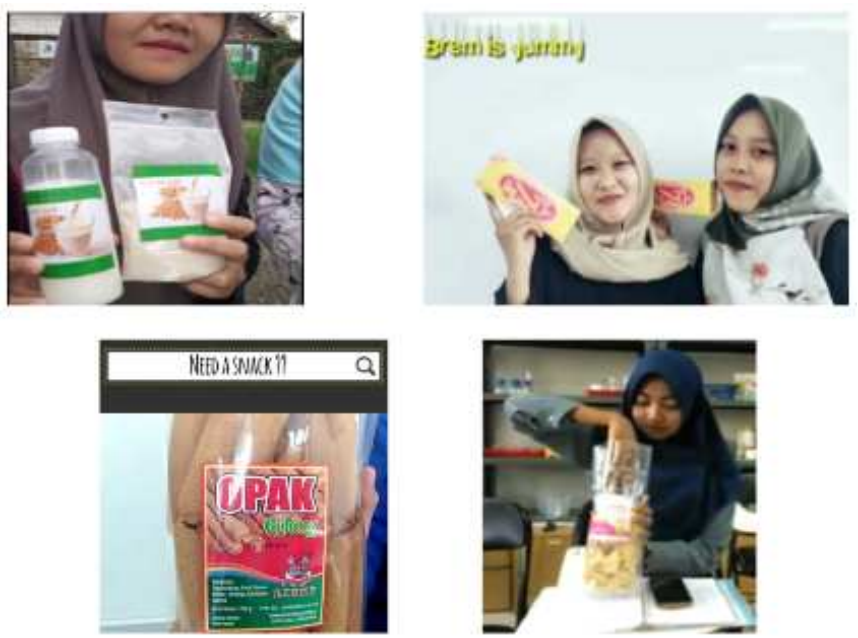

Figure 1. Part of digital storytelling video

After video-taking and video-editing, the learners should upload their English advertisement video into their social media. Then, they completed peer-assessment forms for their classmates' digital stories. The list of peer assessment's statements was made by the lecturer to guide the learners in commenting the other groups. Most of the learners gave the evaluation to their friends' digital storytelling video critically. The learners would like to evaluate whether their friends' digital storytelling video are interested and interactive or not. Besides that, the learners also would evaluate their friends' pronunciation when they had had conversation in the video. Most of the learners being active and critical to give their opinion towards the others. The learners would say honestly what they have watched, heard and observed. Through this peer assessment activity, the learners showed their ideas expressively in the classroom. They felt confident to share their comments to their friends' digital storytelling video without have any embarassed feeling.

After the learners have made their peer-assessments, they replied the comments of the other peers. Besides that, the learners also wrote their selfassessment. They have to give a tick to number that suits best their capacity. The overall results were very encouraging the learners that digital storytelling had helped them to develop different skills, such as writing, pronunciation, listening, digital technology, linguistic, problem solving, and critical thinking skills. In addition, most of the learners stated that digital storytelling can 
improve their self confidence in English public speaking skill. They can express their feelings through this video content. The process of editing video prevented the learners to feel anxiety in wrong pronunciation, so they can perform perfectly. Moreover, the learners feel happy because they utilized social network and technology to followed the government's program in industrial revolution 4.0.

On the other hands, the learners stated that they had learnt marketing knowledge besides learning English through digital storytelling activity. Through digital storytelling activity, the learners started to learn how to attract the audiences on their social media account. Besides that, they tried to promote their agricultural products in English using influential words. In this case, their ability to catch the audiences to watch their advertisement video could increase their rating of respondents. On the other hands, their existences on the social media could improve their contents value and absolutely bringing the positive feedbacks. Indirectly, this situation would sharpen their marketer skill. It will help them to develop their own business after graduated from the polytechnic program.

Besides submitting the advertising video, the learners also did presentation in front of their classmates. They had to explain the process of making the video and the product completely through "making-of" presentation. In addition, the learners had practised to be more confident in speaking English through presentation directly besides they were being creative to make product-advertising video. The result of peer-assessments of "making-of" presentation showed that the learners were being more active and fluent in speaking English in front of the audience than before.

After that, the researcher conducted final survey to the learners who have followed the treatment by using digital storytelling. Most of the learners stated that they were be able to understand English advertisement easily. The English course being active, attractive and enjoyable. The learners also agreed that digital storytelling could develop their writing skill and speaking skill in English. Their interest to the use of technology and social network could bring them to comprehend the procedures of digital storytelling in learning English completely. Besides that, the learners agreed that digital storytelling can help them in promoting their agricultural products as globally. On the other words, it can be stated that digital storytelling can develop their marketing skill in industrial sector. The learners' self-confidence in public speaking activity through digital storytelling would make them being active and interactive. According to the advertising video that the learners have made, they brought it expressively. Most of the learners felt high motivated after they had followed the English learning by using digital storytelling. They had shown positive feedbacks of this activity in overall.

Moreover, it means that the use of digital storytelling has the strong improvement and bring the positive feedback between before and after the treatment towards the knowledge of English advertisement in supporting industrial revolution 4.0 by fourth semester learners of Technology of Agricultural Product study program at PDD UNS. Nevertheless, there were some weaknesses of by using digital storytelling in English learning. The learners would have some difficulties if there was no internet access. Besides, electronic tools such as handycam or camera recorder is needed to record the 
Lestari, R.P., \& Nirmala, D.(2020). Digital storytelling of English advertisement in ESP teaching in Indonesia. EduLite: Journal of English Education, Literature, and Culture, 5 (1), 66-77. DOI: http://dx.doi.org/10.30659/e.5.1.66-77

video. Then, a video-editing skill also can be determining whether the video plot is good or not. According to the result which has shown above, it can be stated that the activeness of the learners depend on how the lecturer bring the material during teaching learning process. Through the attractive teaching method or technique, it can help the learners to build their self-confidence.

Nevertheless, there were some weaknesses of using digital storytelling in English learning. The learners would have some difficulties if there was no internet access in their study area. Internet access has the important part in making digital storytelling. It could transfer the data fastly to the social media. It means that internet media could be the learners' media in connecting their projects to the audiences over the world. Besides, electronic tools such as handycam or camera recorder is needed to record the video. It is possible to use their cellphone's camera in making digital storytelling, but it would be more effective if only using a good quality camera recorder or handycam. Then, a video-editing skill also can be determining whether the video plot is good or not. It would be difficult if only the learners did not have technology skill in video editing because there were many steps in application to conduct the process of video editing. It can be concluded that the learners should obtain a deep understanding of multimedia skill besides English, agricultural and marketing knowledge. Indirectly, digital storytelling could be the effective teaching in learning method in gaining overal skills.

Based on the observation, the are many English lecturers in polytechnic level mostly still use teacher-centered approach in teaching English for specific purpose. This condition causes the learners being passive and only listening the lecturer's explanation till the end of the lesson. The use of technology could help the learners to improve their achievements in English learning process. Shortly, the learners interest of technology and social network automatically could influence the improvement of their active in English learning process. On the other hand, the polytechnic learners have been prepared as skilled technicians for industrial revolution 4.0 both nonlinguistic skills as well as productive linguistics skills through digital storytelling. By comparing the growing needs of the industries with the academic input, the learners have learnt how to measure food's nutrient standard, how to process the basic materials and how to market their served agricultural products by using digital English advertisement video completely.

\section{CONCLUSION}

The development of 4.0 industrial revolution era can be implemented through teaching learning process to the polytechnic learners to prepare them as skilled labours in the real work field. PDD UNS as polytechnic institution has the primary objective to produce the best technicians by comparing the growing needs of the industries with the academic input. Through English teaching program, the learners of Technology of Agricultural Product study program learns English related on food's nutrient standard, processing, and marketing of the agricultural product. The researcher had tried to combine the learners' agricultural knowledge and English material especially in advertisement. The learners had learnt of how to market the traditional agricultural product in Madiun by using digital storytelling. 
There is clear evidence from the final survey that digital storytelling could help the learners in English advertising of their agricultural products. Meanwhile, the use of digital storytelling could improve both linguistic and non-linguistic skills towards the learners of Technology of Agricultural Product study program in PDD UNS. Speaking, writing, and critical thinking were mainly practised through digital storytelling. The learners could develop their writing skill through script-writing, preparing the "making of" presentation, and filling in the assessment forms. Then, the learners could develop their pronunciation skill through working collaboratively in group by using English, recording the English advertising video, and delivering their "making-of" presentations. There were some weaknesses of by using digital storytelling in English learning. The learners would have some difficulties if there was no internet access. Besides, electronic tools such as handycam or camera recorder is needed to record the video. Then, a video-editing skill also can be determining whether the video plot is good or not. However, the learners could develop their critical thinking through self and peer assessment activity after video-uploading by raising their awareness of the skills and competences simultaneously. It would guide the learners to make reflection towards their class activity.

\section{REFERENCES}

Alexander, B. (2011). The new digital storytelling: Creating narratives with new media. 27-28. Stanford University: Praeger.

Bourdaa, M. (2012). This is not marketing. This is HBO: Branding HBO with transmedia storytelling. Networking Knowledge 7(1).

Burnett, C. (2010). Technology and literacy in early childhood educational settings: A review of research. Journal of Early Childhood Literacy, 10, 247-270.

Campbell, T.A. (2012). Digital storytelling in an elementary classroom: Going beyond entertainment. Social and Behavioral Sciences 69, 385-393.

Ferdiansyah, S. (2017). Digital Storytelling. English Teaching Professional, issue 111, 52-56.

Gimeno-Sanz, A. (2015). Digital storytelling as an innovative element in English for specific purposes. Social and Behavioral Sciences 178, 110116.

Hausknecht, S., Orosco, M.V., \& Kaufman, D. (2018). Digitising the Wisdom of Our Elders: Connectedness through Digital Storytelling. 1-21. Retrieved on May 2, 2019 from www.cambridge.org.core

International Ristekdikti. January 2018. Students need to be taught with skills necessary to cope with industrial era. Retrieved on May 7, 2019 from https:/ /international.ristekdikti.go.id/news/students-need-to-be-taughtwith-skills-necessary-to-cope-with-industrial-era/ 
Lestari, R.P., \& Nirmala, D.(2020). Digital storytelling of English advertisement in ESP teaching in Indonesia. EduLite: Journal of English Education, Literature, and Culture, 5 (1), 66-77.

Jimenez, M., Perez, C. \& Zambrano, E. (2014). Del valor educativo de los medios de comunicacion: una aproximacion al caso audiovisual. Ambitos Review. International Review of Communication, n.25. In Digital Advertising Storytelling: Consumer Educommunication. International Review of Communication and Marketing Mix. 1(1), 1-21. DOI:http://dx.doi.org/10.12795/IROCAMM.2018.i1.02

Kajder, S.B. (2006). Bringing the outside in: Visual ways to engage reluctant readers. Portland, ME: Stenhouse Publishers.

Lee, L. (2011). Blogging: Promoting learner autonomy and intercultural competence through study abroad. Language Learning and Technology, 15, 87-109.

Lee, L. (2014). Digital new stories: Building language learners' content knowledge and speaking skills. Foreign Language Annals, 47, 338-356.

Muna, F. May 2, 2018. Analyzing the Prospects and Challenges of Industry 4.0 Implementation in Indonesia. Retrieved on May 7, 2019 from http://theinsiderstories.com

Rance-Roney, J. (2008). Digital Storytelling for Language and Culture Learning. Essential Teacher 5(1):29-31. Retrieved on May 2, 2019 from www.tesol.org

Razmi, M., Pourali, S., \& Nozad, S. (2014). Digital storytelling in efl classroom (oral presentation of the story): A Pathway to improve oral production. Social and Behavioral Sciences 98, 1541-1544.

Robin, B.R. (2008). Digital storytelling: A powerful technology tool for the $21 \mathrm{st}$ century classroom. Theory Into Practice, 47, 220-228.

Vinogradova, P., Linville, H.A., \& Bickel, B. (2011). Listen to my story and you will know me". Digital stories as student-centered collaborative projects. TESOL Journal, 2, 173-202.

Vygotsky, L.S. (1978). Mind in society. Cambridge, M.A.: Harvard University Press.

Widodo, H.P. (2016). Engaging young learners of english in a genre-based digital storytelling project final report. Cambridge: Cambridge University Press Teacher Research Programme. 